\title{
From the Romantic Sea to the Sea as the Global Commons: Portrayals of the Waterbody in Longfellow, Melville, and Ian Wedde
}

\author{
Keiko Fujie \\ Ehime University, Ehime, Japan
}

\begin{abstract}
This article discusses the representation of the sea in selected works of W. H. Longfellow, Herman Melville, and Ian Wedde, tracing its transformation from a romantic icon to a global commons. Despite differences in their portrayals, all three artists find stagnation alongside vitality in the ebb and flow or the rolling of the sea. Similar to Longfellow, Melville romanticizes the sea in Moby-Dick as an ultimate sanctuary, the domain of reveries. At the same time, Melville also portrays the sea as a global commons where U.S. capitalism dominates the global order and exploits the resources. In addressing the environmental issues such as the possibility of whales' extinction, Melville echoes "the tragedy of the commons" lamented by Garrett Hardin. Queequeg, the "primitive" man who saves Ishmael from the wolfish industrial capitalism is thought to be modeled after a Māori from New Zealand. Today, the Māori's ancestral sea-based culture is threatened by economic globalization. Wedde, a New Zealand poet, confronted the plans to construct an aluminum smelter in his country. His poem juxtaposes themes of precariousness and desolation with resilience and defiant survival, a motif mirrored in Longfellow's and Melville's portrayals of the sea.
\end{abstract}

Keywords: ocean, global commons, romantic icon

\section{Introduction}

The sea, which covers nearly three-quarters of the earth's surface, is the anciently recognized global commons. According to the World Conservation Strategy, "A commons is a tract of land or water owned or used jointly by the members of a community. The global commons includes those parts of the Earth's surface beyond national jurisdictions-notably the open ocean and the living resources found there-or held in common—notably the atmosphere".

This article discusses the literary representation of the sea, tracing its transformation from a romantic icon to being a part of the global commons, in selected works of Henry Wadsworth Longfellow (1807-1882), Herman Melville (1819-1891), and Ian Wedde (1946- ), the contemporary New Zealand poet. The representation of the sea changes as the environmental issues such as pollution and the depletion of the resources become serious due to the development of industrial capitalism.

Similar to Longfellow, Melville symbolized and romanticized the sea as the domain of reveries. At the

Keiko Fujie, Ph.D., Professor, Ehime University.

${ }^{1}$ See https://portals.iucn.org/library/efiles/html/WCS-004/section26.html. 
same time, Melville looked at the sea as a real environment and portrayed it as a part of global commons. He was aware of the environmental issues caused by the exploitative whaling fisheries.

Queequeg in Moby-Dick, the "primitive" man whose coffin life-buoy saves Ishmael from drowning is thought to be modeled after a Māori from New Zealand. Today, the Māori's ancestral sea-based culture is endangered by economic globalization. Ian Wedde, a New Zealand poet, collaborated with Māori artists and wrote poems for the protection of the coastal marine environment through Māori spirituality.

Despite differences in their portrayals, all three writers find stagnation alongside vitality in the ebb and flow of the sea. They also find in the eternal tides of the sea the cosmic forces beyond human capacity and anthropocentric system.

\section{Longfellow and Melville's Romantic Sea}

Longfellow was born in Portland, Maine, in New England. His sensibility was, from the beginning, molded by the presence of the sea-by its calm or stormy beauty, its mysterious horizons, its endless shifting aspects, its ebbing and flooding tides, and the sands and rocks of its rugged coastline. It is not an exaggeration to call him a poet of the sea. Van Wyck Brooks, in The Flowering of New England, 1815-1865, asserts that "Longfellow's mind was never far from the sea" (1981, p. 307). He knew both the charm and the terror of the sea, both the mysterious attraction of the sea and its peril. For him, poetry itself was metaphorically the sea, because in "Milton" (1873), he compared Milton to the most powerful wave of the sea.

Longfellow had a romantic soul, which was nurtured by his travel experience to Europe. He was fascinated by European romanticism. His romantic longing for the past and its primitive existence should not be neglected. Like Melville, Longfellow had a friendly sentiment toward people other than Anglo-Americans, especially Native Americans. In "The Song of Hiawatha" (1855), a narrative poem with a rhythm, he used the form derived from the Finnish Kalevala, an ancient Scandinavian saga. Hiawatha is a Native American, a noble savage, who fasts and prays not for himself but for the benefit of the people and advantage of the nation. Longfellow was interested in primitive existence, the primitive people's nature worship, their communion with people and nature, and their view of life and death as natural cycles.

Traditional romantic imagery portrays the sea as the ultimate sanctuary or the domain of reveries. It is an alternative vision to America's relentless market economy. Like a traditional romantic poet, Longfellow portrayed the sea full of romantic legends, myths, and mystery. In "The Secret of the Sea" (1850), the poem's speaker begins the poem as follows: "Ah! What pleasant visions haunt me / As I gaze upon the sea! All the old romantic legends, / All my dreams, come back to me" (Longfellow, 2012, p. 6). He recalls the experience of a landsman, the Spanish Count Arnaldos, who asks an ancient helmsman to teach him the song he was singing. The helmsman replies that the song is about the "secret of the sea", and continues to say, "Only those who brave its dangers / Comprehend its mystery!" (Longfellow, 2012, p. 6). At the end of the poem, the speaker gazes out to sea with the same unfulfilled longings as Count Arnaldos.

Joseph Flibbert indicates that the scene is reminiscent of the first chapter of Moby-Dick (1995, p. 110), in which "thousands upon thousands of mortal men fixed in ocean reveries" (Melville, 1988, p. 4). They are "water-gazers" (Melville, 1988, p. 4). Like Narcissus, they are drawn to the sea by "the image of the ungraspable phantom of life" (Melville, 1988, p. 5). "Meditation and water are wedded forever" (Melville, 1988, p. 4), confirms Ishmael, the narrator.

In chapter 35, "The Mast-Head", Ishmael again tells about the romantic ocean reveries and takes the ocean 
as the visible image of the soul. He relates how a "romantic, melancholy, and absent-minded" (Melville, 1988, p. 158) young man would be "lulled into such an opium-like listlessness of vacant, unconscious reverie" (Melville, 1988, p. 159) and "takes the mystic ocean at his feet for the visible image of that deep, blue, bottomless soul, pervading mankind and nature" (Melville, 1988, p. 159). Ahab, too, like Emerson, regards matter as the manifestation of some transcendental spirit, and he thinks in terms of "linked analogies" between them: "O Nature, and O soul of man! how far beyond all utterance are your linked analogies! not the smallest atom stirs or lives in matter, but has its cunning duplicate in mind" (Melville, 1988, p. 312).

It is natural that Ishmael turns to the sea as a romantic landscape. For Melville, there remains no green field left on land due to its industrial exploitation. "Are the green fields gone?" (Melville, 1988, p. 4). Ishmael poses this rhetorical question in an attempt to explain why he and other people are going to sea. His question indirectly comments on the increasing development of urban areas and the simultaneous loss of meadows and fields during the antebellum period. Carroll Smiths-Rosenberg indicates the over-farming of New England lands and developments in commerce and transportation as the reason (Smith-Rosenberg, 1985, p. 80). Melville's narrator Ishmael comments that "the dreamiest, shadiest, quietest, most enchanting bit of romantic landscape in all the valley of the Saco" (Melville, 1988, p. 4) is the "stream" (Melville, 1988, p. 5) of water. Saco River is in northeastern New Hampshire and southwestern Main.

Ishmael hated the "turnpike earth!一 that common highway all over dented with the marks of slavish heels and hoofs" (Melville, 1988, p. 60), while he admired the "magnanimity of the sea which will permit no records" (Melville, 1988, p. 60). The sea is the "unwarped primal world" (Melville, 1988, p. 414) spreading beyond "the miserable warping memories of traditions and towns" (Melville, 1988, p. 190).

W. H. Auden in The Enchafè Flood discusses the romantic iconography of the sea. He asserts that the sea is the "symbol of primitive potential power as contrasted with the desert of actualized triviality, of living barbarism versus lifeless decadence" (Auden, 1951, p. 27). He cites the typical description of the romantic sea from Moby-Dick: "[A]s this appalling ocean surrounds the verdant land, so in the soul of man there lies one insular Tahiti, full of peace and joy, but encompassed by all the horrors of the half known life" (Melville, 1988, p. 274). Haskell Springer and Douglas Robillard comment on this passage in the following manner: "This island [Tahiti] is not the land, whose values he rejects. Rather it suggests a place of psychological refuge lying somewhere in Ishmael's inner sea" (Springer, 1995, p. 136). David C. Miller comments that Ishmael's "insular Tahiti" is an obsessive vision come from "the depths of the soul", "an inward retreat from the world of economic enterprise and moral endeavor. For us, it is, in Gaston Bachelard's phrase, 'the land of Motionless Childhood.' The sanctuary deep within - the domain of reverie-relates to both the stillness and the narcissism characteristic of luminist painting" (Miller, 1989, p. 237). Both Longfellow and Melville romanticized the sea and united the human soul with the sea.

\section{The Tides of the Sea}

At the same time, both Longfellow and Melville considered the tides and the waves of the sea independent of the human soul and activity. They both found vitality, fertility, and immutability in the ebb and flow or the rolling of the tides of the ocean and contrasted it to human mutability.

Longfellow's "The Wreck of the Hesperus" (1841) (2003b, pp. 228-330) was inspired by a disastrous winter storm off the New England coast on December 14, 1839, and conveys the danger and terror of the sea. It is a threat and menace to the feminine innocence and beauty of the skipper's daughter. After the wreck, the 
"salt sea was frozen on her breast", which was "white as the hawthorn buds", "[t]he salt tears" were in her eyes, which were "blue" "as the fairy-flax", and her fair hair was now "like the brown seaweed". The threat was not so much of an "angry sea" itself as the "cruel rocks". The waves of the sea appeared to be benign because they were "white and fleecy" and looked "soft as carded wool" while the cruel rocks "gored her side/Like the horns of an angry bull". The menace of the sea is covert. The wreck of the schooner Hesperus transformed the daughter's innocent beauty to a tragic death. The endless shifting of the sea, whose "billows fall and rise", seems to be contrasted with the mutability of human life.

The eternal ebbing and flooding and the rising and falling of the tides is the subject of Longfellow's "The Tide Rises, the Tide Falls" (1879) (2003c, p. 258). The traveler does not return to the shore, but the tide rises and falls just like the "morning breaks" and the "day returns" after the darkness of the night. The waves with their "soft, white hands, / Efface the footprints" (Longfellow, 2003c, p. 258) of the traveler in the sand and wash them into oblivion. The constant yet shifting waves of the sea know the mutability of human drama. Longfellow sees the ineluctable pattern not only in the rise and fall of the tides but also in the day's cycle from the light of the day to the darkness of the night and back to dawn.

Longfellow and Melville were both drawn to the sea: The former was drawn to the Atlantic Ocean while the latter to the Pacific Ocean. But their careers as writers were quite different. Longfellow was a Harvard professor, while Melville did not receive any higher education. Melville's narrator Ishmael quotes in Moby-Dick that, not unlike the author, "a whale-ship was my Yale College and my Harvard" (Melville, 1988, p. 112). However, the very last sentence of Moby-Dick reaches the same conclusion that Longfellow does in his poetry, that the sea does not change while humans are mutable: "Now small fowls flew screaming over the yet yawning gulf; a sullen white surf beat against its steep sides; then all collapsed, and the great shroud of the sea rolled on as it rolled five thousand years ago" (Melville, 1988, p. 572).

According to biblical chronology, this is contemporary to Noah's flood. A reference to Noah's flood to underscore the eternity and immutability of the sea is also found in chapter 58, "The same ocean rolls now; that same ocean destroyed the wrecked ships of last year. Yea, foolish mortals, Noah's flood is not yet subsided; two thirds of the fair world it yet covers" (Melville, 1988, p. 273). The sea is an "everlasting terra incognita" (Melville, 1988, p. 273), a mythologized world, unknown to humans. Elizabeth Shultz comments that Melville's concluding passage implies "the power of nature to take care of its own, to restore itself to a prelapsarian condition” (2000, p. 110).

Melville invokes not only the ocean's eternity and immortality but also that of the whale:

[W]e account the whale immortal in his species, however perishable in his individuality. He swam the sea before the continents broke water; he once swam over the site of the Tuileries, and Windsor Castle, and the Kremlin. In Noah's flood he despised Noah's Ark; and if ever the world is to be again flooded, like the Netherlands, to kill off its rats, then the eternal whale will still survive, and rearing upon the topmost crest of the equatorial flood, spout his frothed defiance to the skies. (1988, p. 462)

The entire crew of the Pequod sinks to the bottom of the ocean. Ishmael alone survives, clinging to a coffin made for Queequeg. "But what most commentators neglect to note is that there is another survivor from Melville's book: the whale itself", points out Philip Hoare (2008, p. 359). He also indicates that the whale "remains an immortal, omniscient power" beyond "all human comprehension and physical dimension, forever spinning into space" (p. 359).

Tides are the rise and fall or ebb and flow of the ocean waters. They are actually scientific phenomena. 
Little surface waves are caused by the wind, and the tides or currents of the ocean are caused by the effects of the gravitational forces exerted by the moon and the sun as well as the rotation of the earth. The meteorological forces on the ocean parallel the design of the cosmos in which the planet, the sun, and the moon are eternally found to be in harmonious order. These cosmic forces defy any anthropocentric system. Both Longfellow and Melville probably knew that.

Melville, in Clarel, writes that in Tahiti, "no tides do flow / Or ebb, but waves bide peacefully / At brim, by beach where palm trees grow / That sheltered Omai's olive race- / Tahiti should have been the place / For Christ in advent" (1991, p. 445). For Melville, Tahiti is again a very special place in terms of the tides of the sea. It is scientifically true that there are little or no tides in Tahiti. Rachel Carson in The Sea Around Us (1961) affirms the idea that in Tahiti, "there is very little motion in response to the moon" (2003, p. 192). Nature has its own system independent of humans, whether myth or science.

The White Whale is an "agent" or "principle" (Melville, 1988, p. 164) of the cosmos. The "save the whales, and save the planet" message has been delivered by the medium of the White Whale. The humans cannot expect the cosmos to care about them but the humans should care about the cosmos; for nature or the cosmos will be avenged for the violation of her harmonies. Moby Dick mutilated Ahab's leg in revenge for the exploitative whaling fisheries. Ahab's loss of his leg is described as the working of nature as Moby Dick, with "his sickle-shaped lower jaw beneath him", "reaped away Ahab's leg, as a mower a blade of grass in the field" (Melville, 1988, p. 184).

\section{Melville's Sea as the Global Commons}

\section{The Tragedy of the Commons}

Melville also perceived the sea as a real environment and depicted the sea as a part of global commons: shared by people and other life-forms. The term "commons" is closely related with English social history of the "commons" and the "enclosure". "Commons" referred to traditional rights such as mowing meadows for hay or grazing livestock on common land held in the open field system of old English common law. In Moby-Dick, Melville might be conscious of the historical definition of the commons when he describes Moby Dick "reaping away" Ahab's leg "as a mower". Another pastoral scene is where the right whales graze on brit:

As morning mowers, who side by side slowly and seethingly advance their scythes through the long wet grass of marshy meads; even so these monsters swam, making a strange, grassy, cutting sound; and leaving behind them endless swaths of blue upon the yellow sea. (Melville, 1988, p. 272)

However, the common resources tend to be overgrazed and overexploited as recently lamented by Garrett Hardin. Garrett Hardin proposed the thesis "The Tragedy of the Commons", in which he argued that common resources become overexploited.

Referring to Garrett Hardin's “The Tragedy of the Commons”, Lawrence Buell says,

If there is to be a 'tragedy of commons,' this [the sea] will be the biggest; and the possibility that such a thing might happen has captured international attention more suddenly and dramatically than has the degradation of land or air. (2001, p. 199).

In Moby-Dick, Melville portrays the sea as a part of global commons where U.S. capitalism dominates the global order and exploits the sea's resources. Buell continues to point out:

Moby-Dick was written in and about the moment when the world was coming under the regime of global capitalism. It is 
the first canonical work of Anglophone literature to anatomize an extractive industry of global scope-an industry...where American entrepreneurs had become the leading edge. (2001, p. 205)

The sea through which the Pequod sails are dominated by Yankees and particularly by Nantucket whalemen. The English statesman Edmund Burke addressed the Parliament in 1775, stating that there was "no sea but what is vexed by their fisheries" (2003, p. 24).

Melville's whaling travels took place during the early 1840s and Moby-Dick was written between 1850 and 1851. These are the years when whaling in the United States had its most prosperous period. By the 1830s, the United States had the most prosperous and powerful whaling fishery in the world. Melville witnessed the industry at its zenith. Melville's narrator Ishmael boasts that "we whalemen of America now outnumber all the rest of the banded whalemen in the world" (Melville, 1988, p. 109), and that "the Yankees in one day, collectively, kill more whales than all the English, collectively, in ten years" (Melville, 1988, p. 239).

In the 18th and 19th centuries, hundreds of ships plied the oceans in search of the oil which could be obtained from whales. Sperm whales could yield dozens of barrels of oil from their blubber and the spermaceti from the whale's head. The oil burned in millions of lamps, was used as a machine lubricant, and was processed into candles. Whalebones could be used for corsets, whale skin could be used for leather, and ambergris could be incorporated into perfumes. Whaling quickly came up against the limits of its resources. Hunting grounds near North America were wiped out by early 19th century (New York Times). Melville's story is, as Andrew Delbanco, the author of Melville: His World and Work, states, "certainly among many other things, a cautionary tale about the terrible cost of exploiting nature for human wants. It is a story about self-destruction visited upon the destroyer-the apocalyptic vision at the end seems eerily pertinent to today" (Kennedy, 2010). ${ }^{2}$

In the novel, the possibility of the whale's extinction is addressed. Ishmael questions himself

whether Leviathan can no longer endure so wide a chase, and so remorseless a havoc; whether he must not at last be exterminated from the waters, and the last whale, like the last man, smoke his last pipe, and then himself evaporate in the final puff. (Melville, 1988, p. 460)

Comparing the whale's extinction with the buffalo's, he continues to say:

Comparing the humped herds of whales with the humped herds of buffalo, which, not forty years ago, overspread by tens of thousands the prairies of Illinois and Missouri, and shook their iron manes and scowled with their thunder-clotted brows upon the sites of populous river-capitals, where now the polite broker sells you land at a dollar an inch; in such a comparison an irresistible argument would seem furnished, to show that the hunted whale cannot now escape speedy extinction. (Melville, 1988, p. 460)

In addition, whaling industries produce pollution. Moby-Dick is no longer an epic hunting story, but a horrible vision of industrial hell. Reducing whale blubber to oil produces pollution as described in the following:

Would that he consumed his own smoke! for his smoke is horrible to inhale, and inhale it you must, and not only that, but you must live in it for the time... It smells like the left wing of the day of judgment; it is an argument for the pit. (Melville, 1988, p. 422)

The technology of whale oil production produces poisonous smoke and soot. This vision of infernal

${ }^{2}$ See http://www.nytimes.com/2010/06/13/weekinreview/13kennedy.html. 
enterprise is apocalyptic:

\begin{abstract}
The burning ship drove on, as if remorselessly commissioned to some vengeful deed... The smoke rolled away in sullen heaps... as the wind howled on, and the sea leaped, and the ship groaned and dived, and yet steadfastly shot her red hell further and further into the blackness of the sea and the night, and scornfully champed the white bone in her mouth, and viciously spat round her on all sides; then the rushing Pequod, freighted with savages, and laden with fire, and burning a corpse, and plunging into that blackness of darkness, seemed the material counterpart of her monomaniac commander's soul. (Melville, 1988, pp. 422-423)
\end{abstract}

C. L. R. James points out that Ahab, "the monomaniac commander", faces the "fearful mechanical power of an industrial civilization" (1953, p. 11). Ahab himself is depicted in terms of industrial and mechanized images: iron rails, manufactured body parts, carpentry, hammer, and forge. Whale oil equals profit. The profit-seeking industrial capitalism in the oceanic realm links the idea of Manifest Destiny with progress of Americanization, imperialism, and globalization. It has the environmental effects such as pollution generated by its destructive manufacturing process.

An oil spill is mentioned. Starbuck notices the leakage of whale oil in the casks on board. He exclaims, "The oil in the hold is leaking" (Melville, 1988, p. 474). It is a waste of whale oil, which produces great profits. But Captain Ahab responded "Let it leak!". He continues to say, "There is one God that is Lord over the earth, and one Captain that is lord over the Pequod" (Melville, 1988, p. 474). The spilling of whale oil in Moby-Dick may presage the modern petroleum industry's catastrophic accidents. In the New York Times article, "The Ahab Parallax: 'Moby-Dick' and the Spill”, Randy Kennedy mentions the 2010 Gulf of Mexico oil spill and quotes Andrew Delbanco: "It is irresistible to make the analogy between the relentless hunt for whale oil in Melville's day and for petroleum in ours" (2010). Philip Hoare also points out, "The whaler was a kind of pirate-miner-an excavator of oceanic oil, stoking the furnace of the Industrial Revolution as much as any man digging coal out of the earth" (2008, p. 108).

\title{
Globalism and Ecoglobalism
}

The industrial economic enterprises of the growing industry directly parallel the hierarchy of men on the Pequod. It is a ship of men from all corners of the globe. At the lowest ranks of the ship are men of other races and nationalities, with New Englanders at the helm. Buell calls the multiethnic composition of the Pequod "a global village of ethnicities" (2001, p. 205) in which "the native American liberally provides the brains, the rest of the world as generously supplying the muscles" (Melville, 1988, p. 121).

The expansionist impulse has cultural and political-economic dimensions of globalism: "Let America add Mexico to Texas, and pile Cuba upon Canada; let the English overswarm all India, and hang out their blazing banner from the sun; two thirds of this terraqueous globe are the Nantucketer's" (Melville, 1988, p. 64). This expansionist impulse forced entry into Japan, "If that double-bolted land, Japan, is ever to become hospitable, it is the whale-ship alone to whom the credit will be due; for already she is on the threshold" (Melville, 1988, p. 110). Japan had closed its door to foreign countries and was not hospitable to foreigners at that time.

On the other hand, Melville celebrates whalers and whaling in their voyage on the global scale:

For many years past the whale-ship has been the pioneer in ferreting out the remotest and least known parts of the earth... If American and European men-of-war now peacefully ride in once savage harbors, let them fire salutes to the honor and the glory of the whale-ship, which originally showed them the way, and first interpreted between them and the savages. (1988, p. 110) 
The whalemen made possible "the liberation of Peru, Chili, and Bolivia from the yoke of Old Spain, and the establishment of the eternal democracy in those parts" (Melville, 1988, p. 110). Australia was "given to the enlightened world by the whaleman" (Melville, 1988, p. 110). In the islands of Polynesia, the whale-ship "cleared the way for the missionary and the merchant" (Melville, 1988, p. 110). As Edward Said comments, "Melville's contribution is that he delivers the salutary effect as well as the destructiveness of the American world presence, and he also demonstrates its mesmerizing assumptions about its providential significance" (2000, p. 364). Said also rightly asserts that "only an American could have written Moby-Dick" (2000, p. 358).

Buell proposes the idea that "ecoglobalism... is a whole-earth way of thinking and feeling about environmentality" (2007, p. 227). He continues to say, "the scene of factory-ship confinement and disciplined regimen makes Moby-Dick in important ways a paradigmatic exposé of early industrial overreach" (2007, p. 240). He indicates that "with respect to ecoglobalism, Moby-Dick on cetology far surpasses Walden on limnology" (2007, p. 241). Glen Love also indicates that "Melville's myriad explorations of cetology and natural sciences serve to reprove Ahabian anthropocentrism" (2003, p. 52).

Ahabian anthropocentrism is again criticized in Chapter 44, "The Chart", when Ahab ponders the global movements of the whales. He "knew the sets of all tides and currents" and was thereby arrogantly believing that he could calculate "the driftings of the sperm whale's food" (Melville, 1988, p. 199). A later chapter on measurements of the whale's skeleton (Chapter 103) is also instructive on natural science.

Melville also advances the vision of ecoglobalism against industrial capitalism on a global scale in the chapter "Grand Armada," when the strait of Sunda in Southeast Asia is mentioned:

[A]nd considering the inexhaustible wealth of spices, and silks, and jewels, and gold, and ivory, with which the thousand islands of that oriental sea are enriched, it seems a significant provision of nature, that such treasures, by the very formation of the land, should at least bear the appearance, however ineffectual, of being guarded from the all-grasping western world. (1988, p. 380)

Protected from the "all-grasping western world", mothers of whales nurse their new-born whales, and young whales are "freely and fearlessly" revelled in "dalliance and delight" (Melville, 1988, pp. 388-389).

\section{Melville and Ian Wedde: Māori Spirituality}

Many nature writers have turned to so-called primitive cultures for wisdom. Melville's Queequeg is wise and brave enough to save people and environment. His moral superiority is honored in his friendship with Ishmael, and his communion with nature. Ishmael says, "It is better to sleep with sober cannibals than drunken Christian" (Melville, 1988, p. 24).

Queequeg saves Ishmael from drowning by the coffin-turned life-buoy. The coffin was made at the request of Queequeg when he was close to death. When Queequeg recovers and the coffin is not needed, it is caulked and made into a life-buoy. Queequeg copies the tattooing on his body to the coffin. The tattooings are "all manner of grotesque figures and drawings", perhaps the work of "a departed prophet and seer", Ishmael supposes, perhaps "a complete theory of the heavens and earth" (Melville, 1988, p. 480). "A life-buoy of a coffin!" exclaims Ahab, "Can it be that in some spiritual sense the coffin is, after all, but an immortality-preserver!" (Melville, 1988, p. 528). The primitive people's wisdom to survive the natural disaster must be carved on Queequeg's coffin, copied from his tattoos, and allowed Ishmael to survive.

Queequeg also helps the drowning bumpkin and says to himself, "It's a mutual, joint-stock world, in all meridians. We cannibals must help these Christians" (Melville, 1988, p. 62). Queequeg is brave enough to dive 
into the sea and rescue Tashtego. Tashtego falls down into the whale's head while he is bailing the fragrant sperm out of the whale's head with a bucket. Unfortunately, the whale's head, with Tashtego buried alive in it, drops into the sea. Queequeg demonstrates his great skill in "obstetrics" (Melville, 1988, p. 344) in the process of rescuing Tashtego. Queequeg thrusts back the leg, and delivers Tashtego with head foremost. The whale's head Tashtego has dropped into is compared to a human womb, and Tashtego's deliverance is metaphorically a "delivery" (Melville, 1988, p. 344): Tashtego is born from the whale. Here the borderlines between the human and the non-human almost disappear. The whale is a fellow creature. Queequeg again has wisdom to live with the natural environment and survive the natural disaster.

Queequeg is "a native of Kokovoko, an island far away to the West and South. It is not down in any map; true places never are" (Melville, 1988, p. 55). Kokovoko is an imaginary island, "a utopic alternative to globalization and modernity" (Sanborn, 1998, p. 244). Kokovoko is a private, romantic sanctuary, "insular Tahiti" surrounded by "all the horrors of the half known life" (Sanborn, 1998, p. 274).

Geoffrey Sanborn's recent research discovered that Melville based the character of Queequeg on a Māori chief named Tupai Cupa. Melville drew on a book called The New Zealanders by George Lillie Craik published in 1830. In the novel, Queequeg has "just arrived from the south seas, where he bought up a lot of "balmed New Zealand heads" (Melville, 1988, p. 19) and is "engaged in a cannibal business" (Melville, 1988, p. 19) of head peddling.

"If Queequeg had been from New Zealand—or from anywhere else in the actual world, for that matter-it would have been much more difficult to extricate him from the web of globalization and modernity", writes Sanborn (Sanborn, 1998, p. 241). Queequeg, the primitive man from New Zealand, saves Ishmael not only from drowning but from the "wolfish world" (Melville, 1988, p. 51) of industrial capitalism, the "all-grasping western world" (Melville, 1988, p. 380). He is a "soothing savage" (Melville, 1988, p. 51).

Today, the Māori's ancestral sea-based culture is threatened by economic globalization. Multinational corporations placed an aluminum smelter on the sand spit at Aramoana, in Otago, New Zealand. New Zealand poet, Ian Wedde, published the poem "Pathway to the Sea" (1975) and "Letter to Peter McLeavey: After Basho" (2005) to oppose the siting of this smelter. Ian Wedde, along with other New Zealand writers, Cilla McQueen and Hone Tuwhare and artist, Ralph Hotere, used poetry to intensify involvement in environmental protection. Hotere and Tuwhare are Māori descendants.

Teresa Shewry points out that their "political, environmental, social, and personal" involvement suggests that they understand the sea as a part of the global commons (2011, pp. 247-248). She continues to emphasize that contemporary scholars such as Vandana Shiva describe how people's access to environments like the sea is threatened through the processes of economic globalization and political governance that privatize or centralize environmental control (Shewry, 2011, p. 248).

In "Pathway to the Sea", the narrator speaks about working with others to dig a drain to divert runoff and stop the sludge from entering waterways and presumably, taking a pathway to the sea. The poem is dedicated "to the belief" that "Aramoana should be left to birds, fish, sand hoppers \& other denizens" who at present "possess it" as far as they are "tolerated by men ambitious for / quick solutions \& profits". This dedication is based on the idea that the sea is a global commons, an environment shared with nonhuman life and with people around the world.

In "Letter to Peter McLeavey: After Basho", Wedde refers to New Zealand artist Colin McCahon's Beach Walk series of paintings. This series depicts McCahon's walk on Muriwai beach in memory of the New 
Zealand poet James K. Baxter, whose spirit had traveled along Muriwai as part of the Māori spirit path taken to Cape Reinga. Both McCahon and Baxter are interested in fusing Māori and Christian elements here. McCahon said, "The Christian walk and the Māori walk have a lot in common" (Simpson, 1995, p. 180). Surveying the sand, sky, and waves in "22 Muriwai" in "Letter to Peter McLeavy: After Basho", Wedde finds that McCahon may be "weeping again":

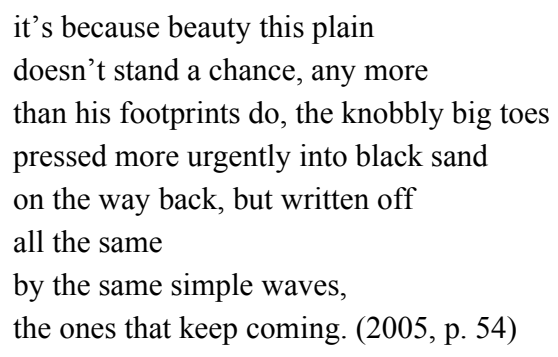

Shewry comments that in the water, "Wedde reads and simply places side by side precariousness and future desolation, as well as resilience and defiant survival... It is a reminder of openness, that not all is given, hope held together with possible losses to come" (2011, p. 259). Because of the siting of the aluminum smelter, the beauty of the beach will be lost just as the footprints are effaced by the "same simple waves / the ones that keep coming" (Wedde, 2005, p. 54). The eternity or immutability of the rise and fall of the tides are again portrayed in contrast to the human mutability. This is the same motif mirrored in Longfellow's "The Tide Rises, the Tide Falls" and the concluding sentence of Moby-Dick.

\section{Conclusion}

The development of industrial capitalism has transformed the portrayals of the sea from a romantic representation to being one of the global commons. Longfellow, Melville, and Wedde have been respectively attracted by the sea. Longfellow and Melville in the early 19th century had a romantic longing for the sea as the domain of reveries. Although the sea was the desert, it was the ultimate sanctuary away from the bustling global economy. But Melville was beginning to be aware that the sea is an actual environment endangered by the exploitative whaling fisheries.

The primitive wisdom not corrupted by civilization common to Longfellow, Melville, and Wedde can save people and the planet. Queequeg originated in Māori in New Zealand. His spirit still exists in New Zealand. Ian Wedde protests through the Māori spirituality the destruction of the coastal marine environment by multinational corporations.

The tides or waves of the sea are caused by the meteorological forces related to the order of cosmos. Glen Love mentions these eternal forces are "limitless dynamism of nature" (2003, p. 52). Despite the differences in their representation of the sea, all three writers equally acknowledged these cosmic forces that are beyond human capacity and defy anthropocentric system.

\section{References}

Auden, W. H. (1951). The Enchafèd Flood; or the Romantic Iconography of the Sea. Boston: Faber and Faber.

Axelrod, S. G., Roman, C., \& Travisano, T. (2003). The New Anthology of American Poetry; Traditions and Revolutions, Beginnings to 1900 (Vol. 1). New Jersey: Rutgers University Press.

Brooks, Van W. (1981). The Flowering of New England, 1815-1865. Boston: Houghton Mifflin.

Buell, L. (2001). Writing for an Endangered World: Literature, Culture, and Environment in the U.S. and Beyond. Massachusetts: 
Belknap Press of Harvard University Press.

Buell, L. (2007). "Ecoglobalist Affects: The Emergence of U.S. Environmental Imagination on a Planetary Scale." In W. C. Dimock and L. Buell (Eds.), Shades of the Planet: American Literature as World Literature (pp. 227-248). New Jersey: Princeton University Press.

Burke, E. (2003). “On Conciliation with America. 1775.” In W. J. Brayan (Ed.), The World's Famous Orations. New York: Bartleby.com.

Carson, R. (2003). The Sea Around Us. New York: Oxford University Press.

Flibbert, J. (1995). "Poetry in the Mainstream.” In H. Springer (Ed.), America and the Sea; A Literary History (pp. 109-126). Georgia: University of Georgia Press.

Flower, D. (2013). "Vengence on a Dumb Brute, Ahab?: An Environmentalist Reading of Moby-Dick." The Hudson Review. Criticism from the Spring 2013 issue. http://hudsonreview.com/2013/08/vengeance-on-a-dumb-brute-ahab-an-environmentalist-reading-of-moby-dick

Hardin, G. (December 1968). "The Tragedy of the Commons." Science, 162, 1243-1248.

Hoare, P. (2008). The Whale; In Search of the Giants of the Sea. New York: Harper Collins.

James, C. L. R. (1953). Mariners, Renegades \& Castaways: The Story of Herman Melville and the World We Live In. Hanover: Dartmouth College.

Kennedy, R. (June 13, 2010). “The Ahab Parallax: 'Moby-Dick' and the Spill." Retrieved from http://www.nytimes.com/2010/06/13/weekinreview/13kennedy.html

Longfellow, H. W. (2003a). “Milton.” In S. G. Axelrod, C. Roman, and T. Travisano (Eds.), The New Anthology of American

Poetry; Traditions and Revolutions, Beginnings to 1900. (Vol. 1) (p. 257). New Jersey: Rutgers University Press.

Longfellow, H. W. (2003b). "The Wreck of the Hesperus." In S. G. Axelrod, C. Roman, and T. Travisano (Eds.), The New Anthology of American Poetry; Traditions and Revolutions, Beginnings to 1900. (Vol. 1) (pp. 228-230). New Jersey: Rutgers University Press.

Longfellow, H. W. (2003c). “The Tide Rises, the Tide Falls.” In S. G. Axelrod, C. Roman, and T. Travisano (Eds.), The New Anthology of American Poetry; Traditions and Revolutions, Beginnings to 1900. (Vol. 1) (p. 258). New Jersey: Rutgers University Press.

Longfellow, H. W. (2003d). “The Song of Hiawatha.” In S. G. Axelrod, C. Roman, and T. Travisano (Eds.), The New Anthology of American Poetry; Traditions and Revolutions, Beginnings to 1900. (Vol. 1) (pp. 241-252). New Jersey: Rutgers University Press.

Longfellow, H. W. (2012). “The Secret of the Sea.” In The Seaside and the Fireside. Rarebooksclub.com.

Love, G. A. (2003). Practical Ecocriticism: Literature, Biology, and the Environment. Charlottesville: University of Virginia Press.

Melville, H. (1988). Moby-Dick, or the Whale. In H. Hayford, H. Parker, and G. T. Tanselle, (Ed.), The Writings of Herman Melville (The Northwestern-Newberry Edition). Chicago: Northwestern University Press.

Melville, H. (1991). Clarel: A Poem and Pilgrimage in the Holy Land. In H. Hayford, A. A. MacDougall, H. Parker, and G. T. Tanselle (Eds.), The Writings of Herman Melville (The Northwestern-Newberry Edition). Chicago: Northwestern University Press.

Miller, D. C. (1989). Dark Eden: The Swamp in Nineteenth-Century American Culture. Cambridge: Cambridge University Press.

Said, E. W. (2000). "Introduction to Moby-Dick." In Reflections on Exile and Other Essays (pp. 356-371). Cambridge: Harvard University Press.

Sanborn, G. (1998). The Sign of the Cannibal: Melville and the Making of a Postcolonial Reader. Durham: Duke University Press.

Sanborn, G. (June 2005). “Whence Come You, Queequeg?” American Literature, 77(2), 227-257.

Schultz, E. (2000). "Melville's Environmental Vision in Moby-Dick." Interdisciplinary Studies in Literature and Environment, $7(1), 97-113$.

Shewry, T. (2011). "Pathways to the Sea; Involvement and the Commons in Works by Ralph Hotere, Cilla McQueen, Hone Tuwhare, and Ian Wedde." In Environmental Criticism for the Twenty-First Century (pp. 247-260) (Edited and introduced by S. LeMenager, T. Shewry, and K. Hiltner). New York: Routledge.

Simpson, P. (1995). "Candles in a Dark Room: James K. Baxter and Colin McCahon.” Journals of New Zealand Literature, 13, 
$157-188$.

Smith-Rosenberg, C. (1985). Disorderly Conduct: Visions of Gender in Victorian America. Oxford: Oxford University Press.

Springer, H., \& Douglas, R. (1995). "Herman Melville.” In H. Springer (Ed.), America and the Sea; A Literary History (pp. 127-145). Georgia: University of Georgia Press.

Wedde, I. (2005). "Letter to Peter McLeavey: After Basho." In Three Regrets and a Hymn to Beauty (pp. 40-67). Auckland: Auckland University Press.

Wedde, Ian. (n.d.). "Pathway to the sea." Retrieved from http://www.nzepc.auckland.ac.nz/authors/wedde/pathway.asp

World Conservation Strategy. (1980). International Union for Conservation of Nature and Natural Resources (IUCN), with the advice, cooperation and financial assistance of the United Nations Environment Programme (UNEP) and the World Wildlife Fund (WWF). Retrieved from https://portals.iucn.org/library/efiles/html/WCS-004/section26.html 